\title{
CONSTITUCIONALIZAÇÃO DO DIREITO ADMINISTRATIVO E A SINDICABILIDADE DO ATO DISCRICIONÁRIO
}

\author{
LUIZ HENRIQUE URQUHART CADEMARTORI ${ }^{\dagger}$ \\ VITÓRIA CRISTINA OLIVEIRA ${ }^{\dagger \dagger}$
}

\begin{abstract}
RESUMO: Com o presente artigo pretende-se tecer uma análise acerca do fenômeno da Constitucionalização do Direito Administrativo, decorrente das transformações no Estado de Direito e, no campo teórico, da mudança de paradigma quanto à exegese do direito, com o advento do neoconstitucionalismo, o qual torna a Constituição Federal parâmetro de interpretação dos demais ramos do ordenamento jurídico. Neste contexto, o conceito de discricionariedade administrativa sofre modificações quanto aos limites de sua interpretação. Por conseguinte, sendo certo que a atividade administrativa é realizada dentro do poder discricionário, tal dever-poder deverá sempre ser utilizado com base em critérios normativos substanciais, de modo a buscar a máxima efetividade dos comandos constitucionais, sendo, assim, plenamente sindicável quanto o controle de excessos ou reconhecimento de legítima opção discricionária.
\end{abstract}

Palavras-Chave: Neoconstitucionalismo; Constitucionalização do Direito Administrativo; Discricionariedade Administrativa.

\footnotetext{
† Pós Doutor em Filosofia do Direito pela Universidad de Granada - Espanha, Doutor e Mestre em Direito Público pela Universidade Federal de Santa Catarina (UFSC), professor permanente do Programa de Doutorado e Mestrado da UFSC, Secretário de Aperfeiçoamento Institucional da UFSC, autor de várias obras e artigos científicos sobre Filosofia do Direito e Direito Público.

${ }^{\dagger}$ Especialista em Direito do Estado pela Universidade Estadual de Londrina (UEL), advogada, pesquisadora na área de Direito Administrativo.
} 
ABSTRACT: The aim of this article is to conduct an analysis of the constitutionalization of Administrative Law, which results from changes in the rule of law and, under a theoretical standpoint, from the paradigm shift of legal exegesis followed by the advent of neo-constitutionalism, which poses the Constitution as the parameter for the interpretation of the other legal branches. Within this context, considering that the concept of administrative discretion goes through interpretation changes and that administrative activity is performed within the boundaries of discretion, this power/duty must always be used with substantial regulatory criteria in order to get the maximum effectiveness of the constitutional rules, thus being subjected to review. In this sense, it is demonstrated that a public official cannot in any way deviate from the realization of the fundamental rights guaranteed by the Constitution, hence stating the reviewability of the administrative discretion.

KEYWORDS: Neo-constitutionalism; Constitutionalization of Administrative Law; Administrative Discretion. 


\section{SUMÁRIO:}

I. INTRODUÇÃO...........................................................................................171

II. A CONSTITUCIONALIZAÇÃo DO DIREITO ADMINISTRATIVO ...........171

III. ANÁLISE DO VOCÁBULO “DISCRICIONARIEDADE" E O MÉRITO

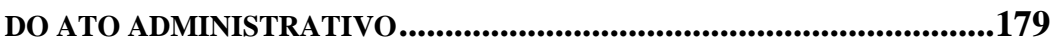

IV. O DEVER-PODER DISCRICIONÁRIO E OS LIMITES DA

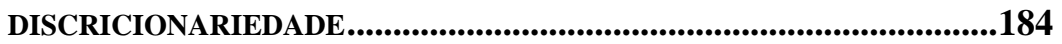

V. CONSIDERAÇÕES FINAIS.............................................................................188

VI. REFERÊNCIAS.........................................................................................189

\section{TABLE OF CONTENTS:}

I. INTRODUCTION .......................................................................................171

II. THE CONSTITUTIONALIZATION OF ADMINISTRATIVE LAW ............171

III. ANALYSIS OF THE TERM "DISCRETION" AND THE ADMINISTRATIVE ACT CONTENT .............................................................179

IV. THE DISCRETIONARY DUTY-POWER AND THE LIMITS OF DISCRETION.......................................................184

V. FINAL CONSIDERATIONS ...........................................................188

VI. REFERENCES .........................................................................................189 


\section{INTRODUÇÃO}

$\mathrm{O}$ artigo tem por finalidade trazer a pesquisa realizada sobre o movimento da constitucionalização do direito e seus reflexos no âmbito da atuação do gestor público, especialmente no que tange aos limites da sua atuação discricionária.

O trabalho se divide em três partes, a primeira se ocupa em trazer à tona a constatação de que essa nova abordagem constitucionalista do direito administrativo decorrente das transformações do Estado, de um lado conduziram a teses nomeadas neoconstitucionalistas ou constitucionalistas de caráter principialista, tornando a Constituição Federal parâmetro substancial a ser observado e orientação axiológica aplicável em qualquer ramo do ordenamento jurídico.

A segunda parte da pesquisa pretende estudar o vocábulo "discricionariedade", de modo a apontar sua real significação no que tange à liberdade do administrador público quanto ao mérito administrativo.

Por fim, sem o objetivo de esgotar a matéria, deveras ampla, a terceira parte busca tecer considerações acerca da sindicabilidade do ato administrativo discricionário, frente aos novos parâmetros de interpretação advindos do constitucionalismo contemporâneo.

\section{A CONSTITUCIONAlizAÇÃo do Direito AdMinistrativo}

Inicialmente, cumpre ressaltar que o novo contexto interpretativo em que se desenvolve a perspectiva da sindicabilidade do mérito na discricionariedade administrativa, subjaz matriz epistemológica do direito denominada, num primeiro momento, de pós-positivismo ou neoconstitucionalismo e hoje tratada por alguns dos seus expoentes como constitucionalismo principialista.

Conforme já exposto em outras obras, o neoconstitucionalismo:

[...] é um fenômeno que transcende a dimensão puramente jurídica, encontrando também os seus fundamentos a partir de uma concepção própria de Estado de Direito e uma nova forma de enfocar o papel da Constituição, por parte dos poderes públicos e da 
própria sociedade. ${ }^{1}$

O conceito, contudo, não é de fácil apreensão, significando modelo de organização jurídico-política, tipo de teoria de direito necessária a explicar tal modelo, podendo, ainda, tratar-se da acepção de neoconstitucionalismo, como ideologia.

Não obstante, é certo afirmar-se que neoconstitucionalismo, é base fundante de uma concepção de Estado de Direito que se traduz em Estado Constitucional, ou seja, que se faz acompanhar de mecanismos jurídicoprocessuais efetivos de implementação normativa e garantias de cumprimento dos direitos fundamentais antes proclamados nos estados liberal e social com fraca densidade regulativa, mesmo no caso de omissões administrativas ou decisões administrativas falhas.

Destarte, o âmbito do constitucionalismo, demanda do intérprete constitucional explorar o sentido da norma, legal ou infralegal, que mais se adapte à Constituição Federal, outrossim, é importante destacar que, considerando-se todos os questionamentos teóricos que as teses ditas neoconstitucionalistas vêm sofrendo, notadamente no campo da teoria do garantismo, optam os atuais expoentes dessa teoria pelo terno constitucionalismo principialista, não como mera mudança terminológica e sim como forma de se afastar de uma designação, oriunda da Escola de Gênova que nasceu permeada de um sentido negativo ou crítico quanto a uma proposta de interpretação axiológica da Constituição, vale dizer, de uma polêmica reaproximação entre o Direito e a Moral.

É nesta conjuntura que se insere uma das facetas da denominada constitucionalização do direito, que tem fundamentos políticos e socioeconômicos.

A necessidade de um Estado Social, ativo, tendente a satisfazer as necessidades da população, mediante a efetivação de direitos e garantias individuais é ambiente propício à constitucionalização. O Estado Constitucional continua a agir por meio da lei, mas a concebe como meio para atingir a determinado objetivo, dentro dos anseios determinados pela Constituição Federal.

Neste panorama, houve um aumento da importância da Constituição

${ }^{1}$ CADEMARTORI, Luiz Henrique Urquhart; DUARTE, Francisco Carlos. Estado de Direito no contexto do Neo-Constitucionalismo e o papel das garantias fundamentais. In: Conselho Nacional de Pesquisa e Pós-Graduação em Direito - CONPEDI (Org.). Anais do XVII Encontro Preparatório para o Congresso Nacional do CONPEDI. Florianópolis, SC: Boiteaux, 2008, p. 3512. 
e o reconhecimento de sua supremacia quando da interpretação e aplicação da norma ao passo que, também das normas constitucionais passou-se a retirar efeito prático, com força e aplicabilidade diretas no plano concreto. Trata-se do efeito expansivo das normas constitucionais, irradiadas por todo o ordenamento jurídico, com força normativa.

No enfoque da Administração Pública, esse fenômeno "limita a discricionariedade, impondo-lhe deveres de atuação e fornecendo fundamento de validade para a prática de atos de aplicação direta e imediata da Constituição, mesmo ante a ausência de atuação do legislador ordinário". ${ }^{2}$

Maria Sylvia Zanella Di Pietro lembra que:

$\mathrm{O}$ direito administrativo nasceu junto com o constitucionalismo. O princípio da legalidade nasceu junto com o princípio da separação de poderes, o princípio da isonomia, o princípio da justicialidade (que exige o controle judicial dos atos estatais). [...] E na Constituição que se encontram os fundamentos dos principais institutos do direito administrativo. ${ }^{3}$

A Constituição Federal de 1988 reafirmou a constitucionalização dos princípios norteadores do direito administrativo que já existia, especialmente a partir da Constituição de 1934, todavia, de maneira mais detalhada e completa, ainda mais com as Emendas à Constituição. As normas da Administração Pública foram elevadas à condição de garantias individuais dos administrados em face do Poder Público, com a finalidade de limitação do arbítrio estatal, obrigando a Administração Pública a ponderar entre a liberdade e autoridade, diante de princípios e metas constitucionais, sendo que a acepção do princípio da legalidade não abarca somente a lei formal, mas todo o arcabouço jurídico. ${ }^{4}$

2 FALDINI, Cristiana Corrêa Conde. A Constitucionalização do Direito Administrativo. In: Maria Sylvia Zanella Di Pietro e Carlos Vinícius Alves Ribeiro (Orgs.). Supremacia do interesse público e outros temas relevantes de Direito Administrativo. São Paulo, SP: Editora Atlas, 2010, p. 265.

${ }^{3}$ DI PIETRO, Maria Sylvia Zanella. Da Constitucionalização do Direito Administrativo: Reflexos sobre o Princípio da Legalidade e a Discricionariedade Administrativa. In: Maria Sylvia Zanella Di Pietro e Carlos Vinícius Alves Ribeiro (Orgs.). Supremacia do interesse público e outros temas relevantes de Direito Administrativo. São Paulo, SP: Editora Atlas, 2010, p. 169.

${ }^{4}$ FALDINI, Cristiana Corrêa Conde. A Constitucionalização do Direito Administrativo. In: Maria Sylvia Zanella Di Pietro e Carlos Vinícius Alves Ribeiro 
O constitucionalismo principialista, por sua vez, trouxe parâmetros norteadores da atividade interpretativa, tais como os explanados por alguns autores da seguinte forma:

[...] o [princípio] da unidade da constituição (a interpretação constitucional deve ser realizada de maneira a evitar contradições entre suas normas); do efeito integrador (na resolução de problemas constitucionais, deverá ser dada primazia aos critérios favorecedores da integração política e social, assim como ao do reforço da unidade política); da máxima efetividade ou eficiência (à norma constitucional deve ser atribuído o sentido que maior eficácia lhe conceda); da justeza ou conformidade funcional (os agentes encarregados de interpretar a Constituição, não poderão chegar a posicionamentos que subvertam, alterem ou perturbem o esquema de organização e funcionamento da Constituição, no seu todo); da concordância prática ou harmonização (combinam-se e coordenam-se os bens jurídicos em conflito, de forma a evitar o sacrifício total de uns sobre outros); da força normativa da Constituição (dentre as interpretações possíveis, deve-se dar preferência à que garanta maior eficácia, aplicabilidade e permanência das normas constitucionais). ${ }^{5}$

Portanto, como consequência da constitucionalização do direito administrativo, o gestor público encontra-se vinculado não apenas à lei stricto sensu, mas diretamente às normas constitucionais, em caráter não só formal mas principalmente substancial, devendo utilizar as formas de interpretação acima elencadas a fim de conferir à aplicação da norma legal a máxima justeza às normas da Lei Maior. Todavia, deve-se estar atendo ao fato de que não parece certo cogitar a possibilidade de descumprir norma positivada a pretexto de melhor atendimento às finalidades constitucionalmente estabelecidas (a menos que seja norma

(Orgs.). Supremacia do interesse público e outros temas relevantes de Direito

Administrativo. São Paulo, SP: Editora Atlas, 2010, p. 267.

${ }^{5}$ CADEMARTORI, Luiz Henrique Urquhart; DUARTE, Francisco Carlos. Estado de Direito no contexto do Neo-Constitucionalismo e o papel das garantias fundamentais. In: Conselho Nacional de Pesquisa e Pós-Graduação em Direito - CONPEDI (Org.). Anais do XVII Encontro Preparatório para o Congresso Nacional do CONPEDI. Florianópolis, SC: Boiteaux, 2008, p. 3518. 
inconstitucional).

Outra consequência, a qual se pretende ater no presente estudo, é a extensão do controle judicial sobre o mérito do ato administrativo, de modo a ver aplicados os princípios e demais normas constitucionais. Acerca deste efeito, pondera Cristiana Correa Conde Faldini:

É certo que a possibilidade de escolha da Administração foi sendo gradualmente restringida (ou disciplinada), desde que o vocábulo passou a integrar a doutrina e a jurisprudência do direito administrativo, no fim do século XIX. Passou-se a exigir a observância da competência, depois regras de forma. Chegou-se às teorias de desvio de poder ou de finalidade. Reconheceu-se a necessidade de fundamentos objetivos de interesse público para a edição dos atos discricionários. A finalidade era tida como centro da legalidade. Fez-se, então, necessária a existência do nexo entre o ato e seus antecedentes ou circunstâncias de fato - motivos. $^{6}$

Destarte, observa-se dessa evolução que o controle da Administração Pública tende a alargar-se ainda mais na tentativa de compatibilizar seus atos à finalidade última de todo o ordenamento jurídico, ou seja, a atenção aos princípios e demais normas constitucionais, com vistas ao atendimento da real finalidade de qualquer norma de ordem pública, o interesse público. Sobre o tema, continua a autora:

Inicialmente insuscetíveis de apreciação pelo Poder Judiciário, aos atos discricionários foram sendo adicionados critérios de ponderação, de controle. O caráter totalmente livre foi se atenuando. Ou seja, além do fundamento legal, explícito ou implícito, a discricionariedade é exercida com base em rede de princípios que evitam seu uso abusivo. A discricionariedade passa a submeter-se à Constituição, à lei, aos princípios gerais de direito. É imperioso o

${ }^{6}$ FALDINI, Cristiana Corrêa Conde. A Constitucionalização do Direito Administrativo. In: Maria Sylvia Zanella Di Pietro e Carlos Vinícius Alves Ribeiro (Orgs.). Supremacia do interesse público e outros temas relevantes de Direito Administrativo. São Paulo, SP: Editora Atlas, 2010, p. 271. 
atendimento do interesse público. ${ }^{7}$

Desta maneira, o mérito administrativo sofre um sensível estreitamento, por decorrência da incidência direta dos ditames constitucionais e alarga-se a possibilidade de interpretação judicial das normas básicas do direito administrativo, ampliando-se a ingerência do Judiciário em matérias tradicionalmente da alçada exclusiva do gestor público, em especial, por medidas judiciais de controle da Administração Pública, notadamente para a proteção de interesses difusos e coletivos, ações coletivas, ação civil pública, mandado de segurança coletivo e ação popular.

A consequência positiva da constitucionalização do direito administrativo é o estabelecimento da ordem de valores que devem ser considerados na atuação administrativa, que servem de parâmetro e limite para o controle de sua atuação, representando instrumento de combate à corrupção e arbitrariedade as quais está sujeita a Administração Pública. Sobre a constitucionalização do direito administrativo na atuação e controle do Poder Público, escreve Cristiana Corrêa Faldini:

É tanto limitação, quanto autorização para atuação. Fundamenta os atos de parte a parte. Tanto o particular e outros legitimados podem controlar a Administração, quanto esta tem expressa indicação de valores que deve considerar em sua atuação. [...] Em suma, amplia a discricionariedade, mas também o controle, em contrapartida. ${ }^{8}$

Assim, a legalidade passa por sensível transformação, o princípio da legalidade, norteador de toda a atividade da Administração Pública experimenta uma evolução, podendo ser referido em dois sentidos: sentido estrito, para designar que certas matérias só podem ser

${ }^{7}$ FALDINI, Cristiana Corrêa Conde. A Constitucionalização do Direito Administrativo. In: Maria Sylvia Zanella Di Pietro e Carlos Vinícius Alves Ribeiro (Orgs.). Supremacia do interesse público e outros temas relevantes de Direito Administrativo. São Paulo, SP: Editora Atlas, 2010, p. 271.

8 FALDINI, Cristiana Corrêa Conde. A Constitucionalização do Direito Administrativo. In: Maria Sylvia Zanella Di Pietro e Carlos Vinícius Alves Ribeiro (Orgs.). Supremacia do interesse público e outros temas relevantes de Direito Administrativo. São Paulo, SP: Editora Atlas, 2010, p. 275. 
disciplinadas por um dos processos previstos no art. 59 da Constituição e o sentido amplo, o qual abrange a lei em sentido formal, os atos normativos do Poder Executivo, órgãos e demais entidades que compõe a Administração direita e indireta, além de todos os princípios jurídicos norteadores do ordenamento, consagrados de forma expressa ou implícita pela Carta Magna. ${ }^{9}$

Neste sentido, Carolina Pereira Barreto pontua que:

A constitucionalização do direito administrativo trouxe a submissão do administrador público ao direito, e não apenas à lei formal, através da aplicação de normas, princípios e valores constitucionais, ao que Maurice Hauriou (apud OLIVEIRA, 2010, p.74-75) convencionou a denominar de "bloco legal" ou "bloco de legalidade", que são as normas, princípios e valores consagrados na Constituição $\left[\ldots . . .^{10}\right.$

A evolução do princípio da legalidade acompanhou as transformações do Estado de Direito, portanto, não se trata mais da legalidade acompanhada do formalismo originário do positivismo jurídico, do texto constitucional decorrem princípios que permitem afirmar-se que o Estado brasileiro trata-se de Estado Constitucional, em substituição ao Estado Legal, revelando-se a preocupação com determinados valores a serem observados no desempenho da função estatal e, dentro desta, a função administrativa, competente à Administração Pública, não mais submetida apenas à lei em sentido formal, mas ainda aos princípios que consagram valores constitucionais, relacionados à liberdade, igualdade, segurança, desenvolvimento social, bem-estar e justiça. ${ }^{11}$

${ }_{9}^{9}$ DI PIETRO, Maria Sylvia Zanella. Da Constitucionalização do Direito Administrativo: Reflexos sobre o Princípio da Legalidade e a Discricionariedade Administrativa. In: Maria Sylvia Zanella Di Pietro e Carlos Vinícius Alves Ribeiro (Orgs.). Supremacia do interesse público e outros temas relevantes de Direito Administrativo. São Paulo, SP: Editora Atlas, 2010, p. 184.

${ }^{10}$ BARRETO, Carolina Pereira. A Constitucionalização do Direito Administrativo: os princípios processuais constitucionais no processo administrativo. In: Ubirajara Coelho Neto (Org.). Temas de Direito Constitucional: Estudos em Homenagem ao Prof.o Osório de Araújo Ramos Filho. Aracaju, SE: Ubirajara Coelho Neto Editor, 2012, p. 109.

${ }^{11}$ DI PIETRO, Maria Sylvia Zanella. Da Constitucionalização do Direito Administrativo: Reflexos sobre o Princípio da Legalidade e a Discricionariedade 
Diante deste panorama, convém transcrever trecho do magistério de Maria Sylvia Zanella Di Pietro:

A Constituição adotou ainda o modelo do Estado Social, fundado na dignidade da pessoa humana e nos valores sociais do trabalho e da livre iniciativa e confirmado no artigo $3^{\circ}$, que atribui à República, entre outros objetivos, o de garantir o desenvolvimento nacional, erradicar a pobreza e a marginalização e reduzir as desigualdades sociais e religiosas, promover o bem de todos, sem preconceitos de origem, raça, sexo, cor, idade e quaisquer outras formas de discriminação; isto sem falar no Título VIII, referente à ordem social, que tem como base primado do trabalho e como objetivo o bem-estar e a justiça sociais (art. 193), com normas em grande parte programáticas, voltadas para a seguridade social, meio ambiente, família, criança. Adolescente, idosos e índios; na maioria dos casos, o Estado desenvolverá atividades com participação da coletividade interessada, acentuando-se o caráter democrático com que se exercerá a administração pública. ${ }^{12}$

Nesse sentido, alargando-se o conceito do princípio da legalidade, possibilita-se considerável ampliação do controle judicial do ato discricionário, que envolve certa margem de apreciação dentro dos limites da lei. Essa constitucionalização que resulta na evolução do referido princípio deu margem à aplicação tardia do que nos Estados Unidos é denominado princípio do devido processo legal em sentido substantivo. Tal princípio permite ao Poder Judiciário rever e anular atos legislativos e decisões administrativas consideradas contrárias aos princípios e direitos fundamentais consagrados pela Constituição. ${ }^{13}$

Administrativa. In: Maria Sylvia Zanella Di Pietro e Carlos Vinícius Alves Ribeiro (Orgs.). Supremacia do interesse público e outros temas relevantes de Direito Administrativo. São Paulo, SP: Editora Atlas, 2010, p. 183.

${ }^{12}$ DI PIETRO, Maria Sylvia Zanella. Da Constitucionalização do Direito Administrativo: Reflexos sobre o Princípio da Legalidade e a Discricionariedade Administrativa. In: Maria Sylvia Zanella Di Pietro e Carlos Vinícius Alves Ribeiro (Orgs.). Supremacia do interesse público e outros temas relevantes de Direito Administrativo. São Paulo, SP: Editora Atlas, 2010, p. 183.

${ }^{13}$ DI PIETRO, Maria Sylvia Zanella. Da Constitucionalização do Direito Administrativo: Reflexos sobre o Princípio da Legalidade e a Discricionariedade 
Ainda em sede do direito comparado, insta destacar que, no ordenamento jurídico francês, "a jurisprudência adotou entendimento de que os regulamentos autônomos baixados pelo Poder Executivo deveriam obedecer aos princípios gerais de direito consagrados no Preâmbulo da Constituição, possibilitando, com isso, seu controle jurisdicional" 14

Deste modo, pode-se dizer que a constitucionalização de princípios e valores, que passaram a integrar o princípio da legalidade e limitar a discricionariedade administrativa, possibilitou controle mais amplo sobre os atos da Administração Pública, o que leva ao reconhecimento de que as normas constitucionais, no campo dos direitos sociais, não são meramente programáticas, tem efetividade decorrente da própria Constituição Federal, obrigando ao Poder Público sua implementação, especialmente, por meio de políticas públicas.

\section{ANÁlISE DO VOCÁBULO “DISCRICIONARIEDADE” E O MÉRITO DO ATO ADMINISTRATIVO}

Embora o verbete "discricionário" signifique, no senso comum, "que procede, ou que exerce, à discrição, sem restrições, sem condições; arbitrário; caprichoso", a discricionariedade com tal concepção somente existiu à época do Estado Absolutista, também denominado Estado de Polícia, no qual o príncipe não se via vinculado a regras jurídicas, configurando um poder sem barreiras institucionais. ${ }^{15}$

O príncipe, no Estado de Polícia, tinha o direito de realizar sempre novos fins por ele delimitados. Assim, não existiam limites legais à atuação do administrador, que não estava vinculado a qualquer norma

Administrativa. In: Maria Sylvia Zanella Di Pietro e Carlos Vinícius Alves Ribeiro (Orgs.). Supremacia do interesse público e outros temas relevantes de Direito Administrativo. São Paulo, SP: Editora Atlas, 2010, p. 194-195.

${ }^{14}$ DI PIETRO, Maria Sylvia Zanella. Da Constitucionalização do Direito Administrativo: Reflexos sobre o Princípio da Legalidade e a Discricionariedade Administrativa. In: Maria Sylvia Zanella Di Pietro e Carlos Vinícius Alves Ribeiro (Orgs.). Supremacia do interesse público e outros temas relevantes de Direito Administrativo. São Paulo, SP: Editora Atlas, 2010, p. 182.

${ }^{15}$ FERREIRA, Aurélio Buarque de Holanda. Novo Aurélio Século XXI: o dicionário da língua portuguesa. 3aㅡ ed. Rio de Janeiro, RJ: Nova Fronteira, 1999, p. 690. 
jurídica a qual os administrados pudessem exigir o cumprimento. ${ }^{16} \mathrm{~A}$ essência deste Estado Absoluto seria, portanto, a discricionariedade como sinônimo de arbitrariedade.

Sobre a discricionariedade no Estado Absolutista, assevera Rita Tourinho:

[...] no regime do Estado de Polícia, a discricionariedade foi a mais ampla. $\mathrm{O}$ administrador, para a prosperidade da comunidade, tinha total liberdade de assumir novos fins e procurar realizá-los fora dos quadros de qualquer regra legal. Não havia direitos subjetivos públicos por parte dos particulares a um comportamento determinado da administração. ${ }^{17}$

Neste período não cabia falar-se em ato administrativo, mas sim, em ato de autoridade, que se impunha obrigatoriamente aos indivíduos, sem qualquer oportunidade de controle popular. Esta era a essência do Estado de Polícia, regime no qual a discricionariedade foi a mais ampla possível.

$\mathrm{O}$ entendimento de discricionariedade como poder ilimitado de escolha foi superado pelo advento do Estado de Direito, no qual toda atividade da Administração Pública deve estar pautada em regras jurídicas que formam não só os limites desta atuação, mas apresentam-se como pressupostos da atuação do Estado.

Entretanto, Estado de Direito e, no atual contexto jurídicointerpretativo, Estado Constitucional de Direito e discricionariedade não são termos contraditórios. A atuação discricionária viabiliza espaço para a atuação da Administração Pública na tomada de decisões, sem que esteja alheia à legalidade e, ainda, à constitucionalidade e à aplicação de todo o arcabouço principiológico que ao lado dela caminha.

Nesta toada, Celso Antonio Bandeira de Mello conceitua a discricionariedade como:

$$
\begin{aligned}
& \text { [... margem de liberdade que remanesça ao } \\
& \text { administrador para eleger, segundo critérios }
\end{aligned}
$$

16 TOURINHO, Rita Andréa Rehem Almeida. Discricionariedade Administrativa: ação de improbidade \& controle principiológico. $2^{a}$ ed. Curitiba, PR: Juruá, 2009, p. 28.

17 TOURINHO, Rita Andréa Rehem Almeida. Discricionariedade Administrativa: ação de improbidade \& controle principiológico. $2^{a}$ ed. Curitiba, PR: Juruá, 2009, p. 28. 
consistentes de razoabilidade, um, dentre pelo menos dois comportamentos, cabíveis perante cada caso concreto, a fim de cumprir o dever de adotar a solução mais adequada à satisfação da finalidade legal, quando, por força da fluidez das expressões da lei ou da liberdade conferida no mandamento, dela não se possa extrair objetivamente uma solução unívoca para a situação vertente. ${ }^{18}$

Discrição é palavra originada do latim discretio de discernere, exprime discricionário o que se põe à discrição de outrem, para que delibere ou resolva, segundo as necessidades do momento ou segundo as circunstância. ${ }^{19}$ Evidencia-se que a raiz etimológica do termo não se afasta do significado de discricionariedade no direito pátrio. Nada mais é que a deliberação, avaliação, escolha, pela autoridade administrativa, por meio de uma análise criteriosa da situação concreta para fiel satisfação da finalidade legal, por meio de uma decisão que mais atenda ao interesse coletivo.

Trata-se de margem de liberdade exercida toda vez que o direito implica a impossibilidade de mera subsunção à hipótese normativa em exame, cabendo a análise da conveniência desta ou aquela interpretação e execução encetada pelo emissor do ato, sob a baliza do interesse público, propiciando a realização da providência mais "justa" no caso concreto.

Assim, a discricionariedade é, antes de tudo, necessária à viabilização da atividade estatal com vistas à efetivação da melhor escolha, desde que tal escolha se traduza na proteção e implementação dos direitos fundamentais, sob a ótica tanto do constitucionalismo principialista como garantista, a despeito de todas as demais polêmicas que cercam ambas as atuais correntes do Direito.

Neste caminho, cabe ressaltar acerca da atividade do administrador público como emissor dos atos estatais, que:

[...] expedi-los não significa necessariamente seguir um ditame ou determinação precisa daquilo que postula a Constituição e suas normas decorrentes. Observe-se, como exemplo disso, a utilização cada vez maior dos princípios que, ao serem observados como exigências de

${ }^{18}$ MELLO, Celso Antonio Bandeira de. Curso de Direito Administrativo. 28 $8^{\mathrm{a}}$ ed. São Paulo, SP: Malheiros, 2011, p. 926.

${ }^{19}$ DE PLÁCIDO E SILVA, Oscar Joseph. Vocabulário Jurídico. 15aㅡ ed. Rio de Janeiro, RJ: Forense, 1998, p. 279. 
otimização, cujo cumprimento pode ser feito em diferentes graus e sob parâmetros valorativos, passam a legitimar, tanto a expedição dos atos estatais quanto o seu controle jurisdicional. ${ }^{20}$

Neste caminho, Eros Grau assevera que a discricionariedade não constitui um poder titulado pela administração, mas, um modo de atuar ao dar cumprimento ao dever-poder de gerir a coisa pública. ${ }^{21}$

A Administração Pública nunca terá liberdade para decidir em dissonância à finalidade última da norma jurídica - o interesse público sob pena de extrapolar o mérito, que é, em suma, "o círculo de liberdade indispensável para avaliar, no caso concreto, o que é conveniente e oportuno à luz do escopo da lei". ${ }^{22}$

Agindo arbitrariamente, o administrador atua segundo seu exclusivo critério, desconhecendo limites jurídicos, conforme a vontade pessoal do titular do poder, que age impulsionado por suas paixões, caprichos e preferências. $^{23}$ Arbitrariedade e discricionariedade são, portanto, conceitos antitéticos.

Sustenta Rita Tourinho que a motivação da decisão é o marco inicial da diferenciação entre arbitrariedade e discricionariedade. ${ }^{24} \mathrm{~A}$ justificação da decisão tomada pelo agente público, sendo necessário que os motivos expostos de fato sejam existentes e suficientes, propicia a análise de seu ato, se condizente ou não à finalidade disposta legalmente.

À Administração Pública impõe-se uma situação de sujeição a esse dever de atingir a finalidade. E para o cumprimento desse dever cabe conferir-lhe certo poder instrumental. Poder no qual está inserido o conceito de discricionariedade, concedido apenas na medida necessária ao atendimento da finalidade legalmente definida.

${ }^{20}$ CADEMARTORI, Luiz Henrique Urquhart. Discricionariedade Administrativa No Estado Constitucional de Direito. $2^{a}$ ed. Curitiba, PR: Juruá, 2007, p. 170.

${ }^{21}$ GRAU, Eros Roberto. Poder Discricionário. Revista de Direito Público, Vol. 23, 93, 1990, p. 41.

${ }^{22}$ MELLO, Celso Antonio Bandeira de. Discricionariedade e Controle Jurisdicional. $2^{\mathrm{a}}$ ed. São Paulo, SP: Malheiros, 2012, p. 82.

${ }_{23}$ TOURINHO, Rita Andréa Rehem Almeida. Discricionariedade Administrativa: ação de improbidade \& controle principiológico. $2^{a}$ ed. Curitiba, PR: Juruá, 2009, p. 49.

24 TOURINHO, Rita Andréa Rehem Almeida. Discricionariedade Administrativa: ação de improbidade \& controle principiológico. $2^{a}$ ed. Curitiba, PR: Juruá, 2009, p. 40. 
Desta forma, entende-se que a discricionariedade não é sinônimo de atuação livre ou arbitrariedade, justifica-se exclusivamente para permitir à Administração adotar a providência ótima no caso concreto, permitindo ao Administrador Público a análise do mérito do ato, que vem a ser:

[...] o campo de liberdade suposto na lei e que efetivamente venha a remanescer no caso concreto, para que o administrador, segundo critérios de conveniência e oportunidade, decida-se entre duas ou mais soluções admissíveis perante a situação vertente, tendo em vista o exato atendimento da finalidade legal, ante a impossibilidade de ser objetivamente identificada qual delas seria a única adequada. ${ }^{25}$

Odete Medauar define o mérito administrativo como expressão do juízo de conveniência e oportunidade efetuado pela autoridade à qual se conferiu o poder discricionário da escolha. ${ }^{26}$ Para ela a discricionariedade pressupõe uma liberdade-vínculo.

Na obra Hely Lopes Meirelles afirma-se que o mérito consubstanciase "na valoração dos motivos e na escolha do objeto do ato, feitas pela Administração incumbida de sua prática, quando autorizada a decidir sobre a conveniência, oportunidade e justiça do ato a realizar" ${ }^{27}$

Conclui-se que, o mérito do ato administrativo é visto como uma liberdade mitigada, entretanto, não se trata de liberdade, mas do dever de avaliar. A análise do mérito, no exercício do poder discricionário, não está ligada a ideia de liberdade, pois a tarefa do administrador é encontrar a única solução adequada para o caso. Sendo possível avaliar dentre um leque de possibilidades, o gestor público deverá realizar a escolha da melhor solução, dentre aquelas igualmente possíveis.

Atuando desta maneira, dentro de determinados limites, não há que se falar em revisão judicial do ato do agente público. Extrapolados tais limites, deixa de existir a discricionariedade e surge a arbitrariedade, propiciando o pleno controle e impedimento do ato pelos órgãos legitimados para tal fim.

${ }^{25}$ MELLO, Celso Antonio Bandeira de. Curso de Direito Administrativo. 28 $8^{\mathrm{a}}$ ed. São Paulo, SP: Malheiros, 2011, p. 918-919.

${ }^{26}$ MEDAUAR, Odete. Direito Administrativo Moderno. 10ª ed. São Paulo, SP: Editora Revista dos Tribunais, 2006, p. 111-114.

${ }^{27}$ MEIRELLES, Hely Lopes. Direito Administrativo Brasileiro. 35ª ed. São Paulo, SP: Malheiros, 2009, p. 158. 


\section{O DEVER-PODER DISCRICIONÁRIO E OS LIMITES DA DISCRICIONARIEDADE}

A função do administrador público, como sujeito encarregado de gerir interesses coletivos, pressupõe o dever de agir em prol de terceiros, no caso, a coletividade. $\mathrm{Na}$ busca de bem realizar tal demanda, a Administração Pública necessita ser dotada de poderes indispensáveis para efetivar ações que visem ao benefício dos administrados. "Logo, a razão de existir este círculo de poderes (competência) é exclusivamente propiciar-lhe que supra os fins legais. Então o administrador dispõe, na verdade, de 'deveres-poderes' (e não poderes-deveres)" pois tais poderes são meramente instrumentais, servientes ao cumprimento do dever de gerir a coisa pública. ${ }^{28}$

Diante de tal desiderato, o dever-poder discricionário, igualmente aos demais poderes administrativos, sobremodo no Estado Constitucional, não constitui salvo conduto para a Administração agir de modo incoerente. A validade de seu uso limita-se ao necessário para alcançar o escopo normativo, consubstanciando-se na escolha da conduta mais clarividente ante as circunstâncias concretas. ${ }^{29}$

Assim, a discricionariedade encontra limites, segundo Celso Antonio Bandeira de Mello, naquilo que ele designa como princípios da proporcionalidade, lealdade, boa fé e igualdade. Portanto, o dever-poder discricionário:

[...] só se justifica, só existe, na medida necessária. Ergo, em todo ato desproporcionado, excessivo, há por definição um excesso em relação à competência, pois não guarda indispensável correlação com ela. [...] Eis porque todo excesso, toda demasia é inválida, viciando o ato. Afinal, como disse Jesus Gonzales Peres, o princípio da proporcionalidade "não postula outra coisa senão uma adequação entre meios e fins". ${ }^{30}$

${ }^{28}$ MELLO, Celso Antonio Bandeira de. Discricionariedade e Controle Jurisdicional. $2^{\mathrm{a}}$ ed. São Paulo, SP: Malheiros, 2012, p. 97.

${ }^{29}$ MELLO, Celso Antonio Bandeira de. Discricionariedade e Controle Jurisdicional. $2^{\mathrm{a}}$ ed. São Paulo, SP: Malheiros, 2012, p. 96-97.

${ }^{30}$ MELLO, Celso Antonio Bandeira de. Discricionariedade e Controle Jurisdicional. $2^{\mathrm{a}}$ ed. São Paulo, SP: Malheiros, 2012, p. 98. 
Tomando-se por base os critérios, no Brasil tratados como princípios, da razoabilidade e proporcionalidade para definir a conveniência e oportunidade do ato administrativo discricionário, será utilizado um juízo de ponderação pelo intérprete, que, ao deparar-se com norma plurissignificativa, deverá determinar-se com a máxima conformidade com a norma constitucional, técnica denominada Interpretação Conforme a Constituição.

Igualmente, os princípios da lealdade e boa-fé são balizas à atuação discricionária, pois, espera-se do agente público um proceder coerente, livre de atos desleais ou que burlem a boa-fé, voltados a tornar concreta a norma consagrada no art. 5ํㅡ, caput, da Constituição Federal, em busca à igualdade dos administrados.

Tratando-se das balizas para o controle da discricionariedade, segundo Maria Sylvia Zanella Di Pietro, pode-se mencionar contribuição da jurisdição administrativa francesa, com a elaboração das teorias do desvio de poder e dos motivos determinantes. ${ }^{31}$ A primeira teoria possibilita a avaliação da finalidade objetivada pela Administração Pública com a prática do ato, para verificar se a autoridade não se utilizou de sua competência para atingir fins diversos dos que decorrem da lei, com isso, há redução da discricionariedade, introduzindo-se o aspecto da moralidade no âmbito do direito administrativo, que passa a integrar a própria legalidade. $\mathrm{O}$ tratamento moral da matéria resultaria incongruente com o direito positivo por ser uma das suas bases a separação entre Direito e Moral, como bem defendem as teses do constitucionalismo garantista, ao reafirmar os postulados positivistas sob um enfoque mais sofisticado e reforçado, rejeitando o constitucionalismo principialista. Entretanto, não é possível elidir o princípio da moralidade plasmado na Constituição Federal do Brasil como um dos norteadores da Administração Pública, o que implica uma leitura axiológica, atenuada por todo o corpo normativo do ordenamento, das condutas e providências administrativas dos agentes públicos.

A teoria dos motivos determinantes, igualmente, limitou a discricionariedade administrativa, na medida em que permitiu o exame da legalidade dos motivos, pressupostos de fato e de direito, que levaram a Administração à prática do ato, permitindo, inclusive, a verificação de se os fatos ocorridos são de natureza a justificar a decisão, permitindo-se

${ }^{31}$ DI PIETRO, Maria Sylvia Zanella. Da Constitucionalização do Direito Administrativo: Reflexos sobre o Princípio da Legalidade e a Discricionariedade Administrativa. In: Maria Sylvia Zanella Di Pietro e Carlos Vinícius Alves Ribeiro (Orgs.). Supremacia do interesse público e outros temas relevantes de Direito Administrativo. São Paulo, SP: Editora Atlas, 2010, p. 184-185. 
ao Judiciário entrar no exame das noções imprecisas, como os conceitos jurídicos indeterminados. Ainda mais, é possível apreciar a adequação da decisão aos fatos, pela aplicação do princípio da proporcionalidade dos meios aos fins. ${ }^{32}$

Portanto, a análise dos limites da atuação discricionária é possível diante da existência dos motivos, ou seja, a demarcação dos pressupostos fáticos cuja decorrência deflagra a competência que o agente possui em abstrato. Ausentes os motivos falta ao gestor público requisito para utilizar-se dos poderes, legitimados e condicionados à presença do evento que lhes justifica o uso, em busca da finalidade legalmente disposta.

Na esteira das reflexões de Celso Antonio Bandeira de Mello, concluise que "o controle dos atos administrativos se estende, inevitavelmente, ao exame dos motivos. A ser de outra sorte, não haveria como garantirse a legitimidade dos atos administrativos." ${ }^{\prime 33}$ A existência de certas circunstâncias fáticas é condição para que a atuação discricionária seja legal.

Ainda que a lei se omita em explicitar os motivos necessários para a produção do ato não se pode chegar à conclusão de que, em tais hipóteses, a Administração poderia agir sem motivos ou que está livre para calcar-se em quaisquer fatos. Nestes casos, deve-se reconhecer, diante da finalidade que visa prover, em quais circunstâncias fáticas a lei será utilizável. Jamais poderá admitir-se que a autoridade expeça um ato sem motivo algum ou por qualquer motivo. ${ }^{34}$

Ensina André Gonçalves Pereira que a causa do ato é relevante fator ao controle de sua legitimidade, assevera que causa é a adequação lógica entre o pressuposto de fato, ou seja, o motivo, e o conteúdo do ato, em vista de uma finalidade legal. ${ }^{35}$

${ }^{32}$ DI PIETRO, Maria Sylvia Zanella. Da Constitucionalização do Direito Administrativo: Reflexos sobre o Princípio da Legalidade e a Discricionariedade Administrativa. In: Maria Sylvia Zanella Di Pietro e Carlos Vinícius Alves Ribeiro (Orgs.). Supremacia do interesse público e outros temas relevantes de Direito Administrativo. São Paulo, SP: Editora Atlas, 2010, p. 184-185.

${ }^{33}$ MELLO, Celso Antonio Bandeira de. Discricionariedade e Controle Jurisdicional. $2^{\mathrm{a}}$ ed. São Paulo, SP: Malheiros, 2012, p. 88.

${ }^{34}$ MELLO, Celso Antonio Bandeira de. Discricionariedade e Controle Jurisdicional. $2^{\mathrm{a}}$ ed. São Paulo, SP: Malheiros, 2012, p. 93-94.

${ }_{35}$ Cf. André Gonçalvez Pereira apud MELLO, Celso Antonio Bandeira de.

Discricionariedade e Controle Jurisdicional. 2ª ed. São Paulo, SP: Malheiros, 2012, p. 122. 
Sobre tal ponto, atesta Celso Antonio Bandeira de Mello:

Com efeito, se o administrador embasa-se em determinados eventos ou situações e diante deles pratica ato desproporcional ao que era requerido para atingir o fim legal ou inapto a lhe dar satisfação, por insuficiente ou excessivo, inadequado, imprestável, verifica-se que os motivos em que se apoiou não eram justificadores da providência; em uma palavra: não podiam ser os motivos implícitos na lei, porque "não haverá correlação lógica necessária" entre o que se tomou como estribo para expedir o ato e o conteúdo dele. ${ }^{36}$

Diante do expendido, a motivação do ato, conceito anteriormente exposto, é requisito para a aferição da correção do ato administrativo. Ausente a motivação, o julgador de sua lisura ética não possuirá meio eficaz para aferir se os motivos, razões e justificativas estiveram ou não embasando o ato questionado, quando de sua produção. Atos expedidos sem motivação ganhariam foros de atos libertos de exigências próprias do sistema normativo, ausentes de legalidade, tais como eram os atos do príncipe, precisamente o que o Estado de Direito veio a abolir. ${ }^{37}$

Assim, a motivação do ato possibilita o controle da discricionariedade, no sentido de que não tenha se vertido em arbitrariedade, uma vez que controlar a atuação administrativa não se limita a um controle técnico, mas, “[...] Ao contrário, estará vinculado a uma integração e correção jurídico-constitucional do ponto de vista substancial dessa atividade" ${ }^{38}$ Em outros termos, pode-se conceber a discricionariedade administrativa em dois planos ou dimensões de análise: por um lado considera-se in abstracto a qual não pode deixar de ser plenamente aceita no ordenamento estatal. Isto porque, dentro de um sistema normativo, a lei em tese faculta, muitas vezes, ao agente público a adoção de medidas em uma ou outra direção, ou de uma ou outra forma, transferindo-lhe a competência para interpretar o sentido da norma que ordena a adoção da providência administrativa mais adequada ao interesse público, conforme o contexto onde possa ser

${ }^{36}$ MELLO, Celso Antonio Bandeira de. Discricionariedade e Controle Jurisdicional. $2^{\mathrm{a}}$ ed. São Paulo, SP: Malheiros, 2012, p. 95.

${ }^{37}$ MELLO, Celso Antonio Bandeira de. Discricionariedade e Controle Jurisdicional. $2^{\mathrm{a}}$ ed. São Paulo, SP: Malheiros, 2012, p. 104.

${ }^{38}$ CADEMARTORI, Luiz Henrique Urquhart. Discricionariedade Administrativa No

Estado Constitucional de Direito. $2^{a}$ ed. Curitiba, PR: Juruá, 2007, p. 174.

2 JOURNAL OF INSTITUTIONAL STUDIES 1 (2016) 
implementada. Justifica-se tal âmbito de discricionariedade, em função de que se encontra superado o antigo modelo burocrático-administrativo descrito por Weber, no qual o agente público era concebido como simples autômato, executor de regulamentos detalhistas e precisos caracterizando a função administrativo como simples execução direta da lei. Tal visão, atualmente, é substituída pelo modelo gerencialista de descentralização ampla da gestão administrativa, o qual confere às diversas unidades da Administração Pública uma ampla liberdade interna, demarcada normativamente, no desempenho das diversas funções, que se baseiam na adoção de medidas autônomas, dentro de parâmetros gerais, ou sob conceitos jurídicos indeterminados, fixados pela lei.

Agora, considerando um segundo nível ou plano da discricionariedade, no seu campo de consecução in concreto entende-se que, implementada a medida, caso o seu destinatário alegue lesão a direitos, o ato administrativo será levado a via judicial, devendo aqui ser amplamente apreciado pelo julgador. Portanto o juiz não somente pode, mas deve analisar - o que não pode ser confundido com substituição de decisões - na sua inteireza, quaisquer atos oriundos do Poder Público, mesmo que seja para reconhecer, uma legítima opção discricionária na qual ele (julgador) não pode interferir. Isto tudo tendo como parâmetros os direitos fundamentais e suas correspondentes garantias, cuja diretriz política estará referida à primazia do administrado frente à Administração, o que seria condizente com o dever-poder administrativo..$^{39}$

Sendo assim, o que se pretende não é defender a eliminação da atividade discricionária, vale dizer, reduzir os atos estatais ao aspecto estritamente vinculante ou tornar o seu mérito totalmente engessado aos ditames judiciais, mas sim limitar a atuação do Poder Público de modo que o poder discricionário não oculte atuação ilegal e arbitrária, destoante do que determina a norma constitucional.

\section{CONSIDERAÇÕES FINAIS}

Realizado o estudo acerca da evolução das técnicas exegéticas do direito, buscou-se demonstrar que, com o advento do Estado Constitucional, a Constituição Federal tornou-se norma aplicável de forma ampla e direta nos demais ramos do direito, trazendo a lume a

${ }^{39}$ CADEMARTORI, Luiz Henrique Urquhart. Discricionariedade Administrativa No Estado Constitucional de Direito. 2ª ed. Curitiba, PR: Juruá, 2007, p. 182-183. 
Constitucionalização do Direito Administrativo, fenômeno este que amplia o controle externo da atividade administrativa, em especial aquela exercida no âmbito da discricionariedade.

Buscou-se, neste sentido, explicitar conceito do termo "discricionário" no âmbito jurídico e, em especial, no contexto do Estado Constitucional, de modo a afastar a ideia de arbitrariedade, demonstrando que os limites de atuação do emissor de atos estatais estão intrinsecamente ligados à perspectiva garantista da proteção e implementação dos direitos positivados pela norma constitucional.

Finalizando, em decorrência de todo o exposto, pode-se afirmar que, sob a ótica do Estado Constitucional, a atuação estatal, a qual engloba a expedição de atos administrativos discricionários, torna-se sindicável mediante os parâmetros de interpretação advindos do neoconstitucionalismo, de modo a possibilitar a proteção e implementação dos direitos fundamentais na sua dimensão formal e substancial.

\section{REFERÊNCIAS}

BARRETO, Carolina Pereira. A Constitucionalização do Direito Administrativo: os princípios processuais constitucionais no processo administrativo. In: Ubirajara Coelho Neto (Org.). Temas de Direito Constitucional: Estudos em Homenagem ao Prof. ${ }^{\circ}$ Osório de Araújo Ramos Filho. Aracaju, SE: Ubirajara Coelho Neto Editor, 2012.

CADEMARTORI, Luiz Henrique Urquhart. Discricionariedade Administrativa No Estado Constitucional de Direito. $2^{\underline{a}}$ ed. Curitiba, PR: Juruá, 2007.

CADEMARTORI, Luiz Henrique Urquhart; DUARTE, Francisco Carlos. Estado de Direito no contexto do Neo-Constitucionalismo e o papel das garantias fundamentais. In: Conselho Nacional de Pesquisa e PósGraduação em Direito - CONPEDI (Org.). Anais do XVII Encontro Preparatório para o Congresso Nacional do CONPEDI. Florianópolis, SC: Boiteaux, 2008. 
DE PLÁCIDO E SILVA, Oscar Joseph. Vocabulário Jurídico. 15ª ed. Rio de Janeiro, RJ: Forense, 1998.

DI PIETRO, Maria Sylvia Zanella. Da Constitucionalização do Direito Administrativo: Reflexos sobre o Princípio da Legalidade e a Discricionariedade Administrativa. In: Maria Sylvia Zanella Di Pietro e Carlos Vinícius Alves Ribeiro (Orgs.). Supremacia do interesse público e outros temas relevantes de Direito Administrativo. São Paulo, SP: Editora Atlas, 2010.

FALDINI, Cristiana Corrêa Conde. A Constitucionalização do Direito Administrativo. In: Maria Sylvia Zanella Di Pietro e Carlos Vinícius Alves Ribeiro (Orgs.). Supremacia do interesse público e outros temas relevantes de Direito Administrativo. São Paulo, SP: Editora Atlas, 2010.

FERREIRA, Aurélio Buarque de Holanda. Novo Aurélio Século XXI: o dicionário da língua portuguesa. $3^{\underline{a}}$ ed. Rio de Janeiro, RJ: Nova Fronteira, 1999.

GRAU, Eros Roberto. Poder Discricionário. Revista de Direito Público, Vol. 23, 93, 1990.

MEDAUAR, Odete. Direito Administrativo Moderno. 10ª ed. São Paulo, SP: Editora Revista dos Tribunais, 2006.

MEIRELLES, Hely Lopes. Direito Administrativo Brasileiro. 35aㅡ ed. São Paulo, SP: Malheiros, 2009.

MELlO, Celso Antonio Bandeira de. Curso de Direito Administrativo. $28^{a}$ ed. São Paulo, SP: Malheiros, 2011. . Discricionariedade e Controle Jurisdicional. $2^{\underline{a}}$ ed. São Paulo, 
SP: Malheiros, 2012.

TOURINHO, Rita Andréa Rehem Almeida. Discricionariedade Administrativa: ação de improbidade \& controle principiológico. $2^{\underline{a}}$ ed. Curitiba, PR: Juruá, 2009.

Constitucionalização do Direito Administrativo e Sindicabilidade do Ato Discricionário Constitutionalization of Administrative Law and Reviewability of the Administrative Discretion Submetido em: 2016-05-13 Aceito em: 2016-07-10 